\title{
NUTRIENT COMPOSITION OF OAK ACORN FLOUR
}

\author{
Helga Sz. Migaskó ${ }^{1}$, Károly Ecseri ${ }^{1^{*}}$ and Judit Pető ${ }^{2}$ \\ 1 Department of Horticulture, Faculty of Horticulture and Rural Development, John von Neumann University \\ ${ }^{2}$ Department of Agricultural Sciences, Faculty of Horticulture and Rural Development, John von Neumann \\ University \\ https://doi.org/10.47833/2020.2.AGR.009
}

\begin{abstract}
Keywords:
pedunculate oak

macro and micronutrients

potassium content

functional food

\section{Article history: \\ Received 25 Sept 2019 \\ Revised 26 Feb 2020 \\ Accepted 5 March 2020}

\begin{abstract}
The nutrients in plant seeds play an important role during germination. At the same time, these nutrient values are also useful sources in human nutrition. The mineral element content of pedunculate oak (Quercus robur) acorn flour was investigated (collected from the Great Hungarian Plain) and compared with literature data. The potassium content was outstanding in the examined sample, which plays a significant role in the optimal functioning of the muscle and nerve tissues and the regulation of the blood glucose level. In addition, we found high values for calcium and iron compared to cereals. This results may justify the use of naturally occurring oak species in the functional foods market.
\end{abstract}

\section{Introduction}

Minerals are that inorganic substances which remain in the ashes after cremation of plant or animal origin food [2].

Minerals are essential for the human body. They play a significant role in the metabolic processes and responsible for the optimal functioning of life processes. They are also determinant factors in regulating of osmosis, acid-base balance and electrochemical system. Some of them are components of connective tissues and control enzymatic reactions [2]. They make up 4.3-4.4\% of our body. Minerals can be divided into two groups, depending on daily intake is above or less than $100 \mathrm{mg}$. The former group are called macronutrients, while the latter are called micronutrients or trace elements [1].

Oilseeds are one of the important sources of nutrients: they contain in larger quantities calcium from the macronutrients and zinc from the micronutrient group [2]. An aqueous extract of Quercus robur acorns also contain magnesium, potassium, phosphorous, iron, copper and manganese [6]. The nitrogen and potassium macronutrient content, as well as the iron and zinc content of the oak acorn must be highlighted [5].

\section{Method}

The fruits were collected under the Quercus robur trees in the northern and central parts of the Great Hungarian Plain (Kecskemét, Nagykőrös, Cegléd) in October, 2018. The fruits were dried at room temperature and ground into flour in the grain mill in the laboratory of the Faculty.

The macro- and micronutrient content was determined by the Soil and Plant Laboratory of John von Neumann University. Nitrogen content was determined by the FOSS Kjeltec 2300 steam distillation and automatic titration machine, according to MSZ-08-1783-6:1983 method. For detection of other macronutrients and micronutrients the JY ULTIMA 2 ICP-OES spectrometer was used, according to MSZ-08-1783-29:1985. The results were compared data in professional literature.

\footnotetext{
* Corresponding author. Tel.: +36 76517 655;

E-mail address: ecseri.karoly@kvk.uni-neumann.hu
} 


\section{Results}

Examining the data, it can be concluded that the highest amount of macronutrients was potassium ( $1.09 \%$ by weight) and nitrogen ( $0.884 \%$ by weight). The value of potassium content is outstanding in comparison with other Quercus data as well as cereal species (corn, wheat, rice) and shelled fruits (macadamia nuts, nuts, hazelnuts) (Table 1). However, the phosphorus content of oaks is lower than value of nuts or grains. The magnesium content of our results was $25-50 \%$ of the magnesium content according to [7] and [4]. There was no significant difference between the cereals and the Quercus robur and Quercus brantii species (Table 1).

Table 1. Macronutrient content of Quercus robur, Quercus brantii and three significant nuts and cereal species (in \% by dry weight)

\begin{tabular}{|c|c|c|c|c|c|c|c|}
\hline Species name & $N$ & $P$ & $K$ & $\mathrm{Ca}$ & $M g$ & $\mathrm{Na}$ & Source \\
\hline Quercus robur & 0.884 & 0.095 & 1.09 & 0.077 & 0.051 & 0.010 & own data, 2019 \\
\hline Quercus robur & 2.118 & 0.090 & 0.784 & 0.109 & 0.074 & 0.013 & [5] \\
\hline Quercus brantii & - & 0.071 & 0.637 & 0.073 & 0.035 & 0.016 & \multirow{4}{*}{ [7] } \\
\hline Zea mays & - & 0.28 & 0.30 & 0.02 & 0.12 & 0.02 & \\
\hline Triticum aestivum & - & 0.31 & 0.42 & 0.05 & 0.10 & 0.06 & \\
\hline Oryza sativa & - & 0.32 & 0.46 & 0.06 & 0.12 & 0.02 & \\
\hline Macadamia integrifolia & - & 0.22 & 0.53 & 0.06 & 0.12 & - & \multirow{3}{*}{ [4] } \\
\hline Juglans regia & - & 0.41 & 0.45 & 0.08 & 0.17 & - & \\
\hline Corylus avellana & - & 0.40 & 0.73 & 0.10 & 0.19 & - & \\
\hline
\end{tabular}

The iron content of our sample is outstanding in Table 2. This value $(197 \mathrm{mg} / \mathrm{kg})$ is more than three times higher than rice which contain the second most iron. In addition, the amount of the other metallic microelement (copper) should be mentioned. The copper content of our sample was double than in wheat or rice. And the same time, the content of manganese and zinc was lower than the cereal grains (Table 2).

Table 2. Microelement content of Quercus robur, Quercus brantii and three important cereal species (in $\mathrm{mg} / \mathrm{kg}$ dry matter)

\begin{tabular}{|c|c|c|c|c|c|c|c|c|}
\hline Species name & $\mathrm{Fe}$ & $M n$ & $Z n$ & $\mathrm{Cu}$ & $B$ & Mo & $\mathrm{Se}$ & Source \\
\hline Quercus robur & 197 & 3.92 & 10.4 & 15.2 & 16.9 & $<0.5$ & - & own data, 2019 \\
\hline Quercus robur & 32 & 7.9 & - & 6.2 & - & - & - & [5] \\
\hline Quercus brantii & 23.67 & 3.2 & 9.17 & 4.63 & - & - & 0.05 & \multirow{4}{*}{ [7] } \\
\hline Zea mays & 45.0 & 7.0 & 18.0 & 3.0 & - & - & 0.03 & \\
\hline Triticum aestivum & 40.0 & 24.0 & 28.0 & 7.0 & - & - & 0.06 & \\
\hline Oryza sativa & 60.0 & 58.0 & 31.0 & 7.0 & - & - & 0.38 & \\
\hline
\end{tabular}

\section{Discussion}

Our sample had higher nutrient values than the literature data in the case of nitrogen, potassium, iron and copper. The human body needs large amounts of potassium ( $2000 \mathrm{mg} / \mathrm{day})$, the metallic microelements are found mainly in seeds [3]. Potassium plays an important role in fluid balance and iron and copper are known to be important in hematopoiesis and oxygen transport [1]. In addition, due to the role of copper in reducing oxidative stress (a component of oxidoreductase enzymes) [2], the fruit of Quercus robur can be perspective in human nutrition as species which can help to expand diversity. 


\section{Acknowledgment}

Thank you for the support of the research carried out in the framework of the EFOP-3.6.2-162017-00012 „Developing a functional, healthy and safe food product chain model from field to table in a thematic research network". The project is funded by the Hungarian State and the European Union, co-financed by the European Social Fund, and is part of the Széchenyi 2020 program.

\section{References}

[1] DARVAY S. (szerk.) (2013): Táplálkozástani és élelmezéstani ismeretek. Líceum Kiadó, Eger pp. 18-19.

[2] FIGLER M. (szerk.) (2015): Élelmiszer-tudományi Ismeretek. Medicina Könyvkiadó Zrt., Budapest. pp. 103-110.

[3] GRUSAK, M. A. - DELLAPENNA, D. (1999): Improving the nutrient composition of plants to enhance human nutrition and health. Annual Review of Plant Physiology and Plant Molecular Biology. Vol. 50. pp. 133-161.

[4] LOTT, J. N. A. and BUTTROSE, M. S. (1978): Location of reserves of mineral elements in seed proteins bodies: macadamia nut, walnut, and hazel nut. Canadian Journal of Botany. Vol. 56. pp. 2072-2082.

[5] NIKOLIĆ, N., ORLOVIĆ, S., KRSTIĆ, B., KEVREŠAN, Ž. (2006): Variability of acorn nutrient concentrations in pedunculate oak (Quercus robur L.) genotypes. Journal of Forest Science Vol. 52 No. 2. pp. 51-60.

[6] RAKIĆ, S., POVRENOVIĆ, D., TEŠEVIĆ V., SIMIĆ, M., MALETIĆ, R. (2006): Oak acorn, polyphenols and antioxidant activity in functional food. Journal of Food Engineering. Vol. 74. pp. 416-423.

[7] SAFFARZADEH, A., VINCZE L. and CSAPÓ J. (1999): Determination of the chemical composition of acorn (Quercus brantii), Pistacia atlantica and Pistacia khinjuk seeds as non-conventional feedstuffs. Acta Agraria Kaposvárensis. Vol. 3. No. 3. pp. 59-69. 